\author{
G. Andersen - J. Overgaard - A. Albrechtsen • \\ C. Glümer · K. Borch-Johnsen · T. Jørgensen · \\ T. Hansen $\cdot$ O. Pedersen
}

\title{
Studies of the association of the GNB3 825C>T polymorphism with components of the metabolic syndrome in white Danes
}

Received: 21 July 2005 / Accepted: 6 September 2005 / Published online: 12 November 2005

(C) Springer-Verlag 2005

\begin{abstract}
Aims/hypothesis: The $825 \mathrm{C}>\mathrm{T}$ polymorphism in the gene encoding the $\mathrm{G}$ protein $\beta 3$ subunit (GNB3) causes enhanced $G$ protein activation and increased in vitro cell proliferation. This polymorphism is also repeatedly associated with an increased risk of hypertension and has been studied in relation to obesity with divergent results. Only a few association studies have investigated whether this polymorphism is related to type 2 diabetes or the metabolic syndrome. We estimated the impact of the GNB3 $825 \mathrm{C}>\mathrm{T}$ polymorphism in relatively large-scale association studies of common phenotypes of the metabolic syndrome. Materials and methods: The GNB3 825C $>\mathrm{T}$ polymorphism was genotyped in 7,518 white Danish subjects using mass spectrometry analysis of PCR products. Case-control studies were undertaken for obesity, hypertension, type 2 diabetes and the metabolic syndrome, and a meta-analysis including data from the present study and previous studies of hypertension was performed. Quantitative trait studies of metabolic variables were carried out in 4,387 glucose-tolerant subjects. Results: We observed minor differences in $825 \mathrm{C}>\mathrm{T}$ genotype distributions for type 2 diabetes (CC/CT/TT 49/41/10\% (control) vs $46 / 46 / 9 \%$ (cases), respectively, $p=0.007$ ); however, after correction for multiple testing, these were not statistically significant. No association was found with hypertension, obesity or the metabolic syndrome. Curiously, the T
\end{abstract}

G. Andersen $(\bowtie) \cdot$ J. Overgaard · A. Albrechtsen · C. Glümer ·

K. Borch-Johnsen · T. Hansen · O. Pedersen

Steno Diabetes Center, Niels Steensens Vej 2,

NSH2.16, 2820 Gentofte, Denmark

e-mail: gtta@steno.dk

Tel.: +45-44437309

Fax: $+45-44438232$

C. Glümer · K. Borch-Johnsen · T. Jørgensen

Research Centre for Prevention and Health,

Glostrup University Hospital, Copenhagen County,

Glostrup, Denmark

K. Borch-Johnsen · O. Pedersen

Faculty of Health Science,

University of Aarhus, Aarhus, Denmark allele was associated with nominally lower systolic and diastolic blood pressure levels-a finding in contrast with most previous studies-but not with other metabolic variables. Meta-analysis demonstrated a high degree of heterogeneity between study populations of different ethnic origin. Although there was a tendency towards an increased risk of hypertension among 825T allele carriers, this was not statistically significant. Conclusions/interpretation: The present study suggests no major involvement of the GNB3 $825 \mathrm{C}>\mathrm{T}$ polymorphism in components of the metabolic syndrome.

Keywords Diabetes · Genetic epidemiology · Hypertension - Obesity

Abbreviations HOMA-IR: homeostasis model assessment of insulin resistance - MAF: minor allele frequency - MALDI-TOF: matrix-assisted laser desorption/ ionisation time-of-flight - OHA: oral hypoglycaemic agent - OR: odds ratio - WHO: World Health Organization

\section{Introduction}

G proteins are heterotrimers consisting of $\alpha, \beta$, and $\gamma$ subunits that relay information from cell surface receptors to effectors from several protein families, including enzymes and ion channels. Due to their pivotal function in many cell types, variation in the genes encoding the subunits of $G$ proteins has the potential to play a role in numerous clinical conditions. Specifically, investigators have studied possible associations of the frequent substitution of a $\mathrm{C}$ with a $\mathrm{T}$ nucleotide at position 825 in exon 10 in the gene encoding the $\mathrm{G}$ protein $\beta 3$ subunit (GNB3), resulting in the silent Ser275Ser polymorphism, with hypertension [1-15] and related cardiovascular phenotypes [16-22], and with obesity [22-25], psychological syndromes [26-28], type 1 diabetes complications (nephropathy, retinopathy and neuropathy) $[29,30]$, type 2 diabetes $[13,22,31,32]$, cancer [33] and various immunological responses [34]. The $825 \mathrm{C}>\mathrm{T}$ polymorphism is associated 
with the occurrence of a splice variant with an in-frame deletion of 41 amino acids (from exon 9) including the fourth of seven Trp-Asp repeats, each consisting of approximately 40 highly conserved amino acids, which normally form a $\beta$-propeller peptide structure [1]. This change gives rise to the functionally active $G \beta 3$-s, and only one $825 \mathrm{~T}$ allele is needed to generate $\mathrm{G} \beta 3$-s, the splice variant [1]. The $825 \mathrm{~T}$ allele is associated with enhanced $\mathrm{G}$ protein activation and, thus, increased cell proliferation [35], and it appears that the 825T allele exerts an additive effect on $G$ protein signalling in vitro as a result of the increased production of G $\beta 3$-s [36].

Human GNB3 is located in a gene-rich cluster on chromosome 12p13 [37, 38] - a locus that has shown linkage with an autosomal-dominant form of hypertension [39] and with BMI [40] and fasting serum total cholesterol levels [41]. Initially, the 825T allele was found to be associated with an increased risk of hypertension in a sample of approximately 850 subjects [1], and this observation was confirmed in independent studies of various sample sizes $[5,17]$. Although a similar tendency of increased $\mathrm{T}$ allele frequency among hypertensive patients was observed in two further additional studies, there was no statistically significant association of this allele with hypertension [8,9]. In addition, data from one study suggested the inverse association-increased $\mathrm{C}$ allele frequency among hypertensive patients - although this finding was not statistically significant [11]. Finally, some studies have shown that hypertensive and normotensive subjects have similar T allele and TT genotype frequencies [2-4].

A strong association of this GNB3 variant with overweight and obesity was observed among German hypertensive patients, and it was suggested that the assumed relationship between hypertension and the variant was precipitated by the effect of obesity on the risk of increased blood pressure and cardiovascular events [25]. Indeed, data from other studies support this notion, even though there are some conflicting results $[12,22-24,42-$ 44]. Likewise, interindividual differences in BMI may also account for the observation that type 2 diabetic patients carrying the $\mathrm{T}$ allele had significantly improved insulin sensitivity compared with homozygous carriers of the $\mathrm{C}$ allele following an intervention-optimisation protocol [45]. However, this interpretation has been challenged by two studies of insulin sensitivity in which the $T$ allele was associated with lower insulin sensitivity after adjustment for BMI [20, 21]. Finally, two moderately sized studies have suggested an association of the $825 \mathrm{~T}$ allele with type 2 diabetes [13, 32].

Possible explanations for the apparent discrepancies in published studies investigating the association of the GNB3 $825 \mathrm{C}>\mathrm{T}$ polymorphism with hypertension and obesity are the use of insufficient sample sizes in some of the studies, differences in ethnicity and phenotype assessment, and a lack of adjustment for confounding effects. Therefore, the aim of the present study was to investigate associations of the GNB3 $825 \mathrm{C}>\mathrm{T}$ polymorphism with common compo- nents of the metabolic syndrome in a relatively large-scale and homogenous sample comprising 7,518 Danes of European extraction. Case-control studies were performed for hypertension, obesity, type 2 diabetes and the metabolic syndrome as defined by the World Health Organization (WHO) in 1999 [46].

\section{Subjects and methods}

Subjects The GNB3 825C $>\mathrm{T}$ polymorphism was genotyped in a total of 7,518 Danes of European extraction who were divided into three study groups: (1) a population-based sample (Inter99) of middle-aged white Danes who were living in the greater Copenhagen area and were sampled at the Research Centre for Prevention and Health [47]; (2) a group of type 2 diabetic patients who were sampled through the outpatient clinic at the Steno Diabetes Center; and (3) a population-based group of middle-aged glucose-tolerant subjects who were recruited from the Research Centre for Prevention and Health [48]. Study group 1 ( $n=6,182 ; 3,009$ men, 3,173 women) was $46 \pm 8$ years old $\left(\right.$ mean \pm SD) and had a BMI of $26.3 \pm 4.6 \mathrm{~kg} / \mathrm{m}^{2}$. Of the 6,182 participants, 4,387 (71\%) had normal glucose tolerance, $1,164(19 \%)$ had impaired fasting glycaemia or impaired glucose tolerance, and $358(6 \%)$ had either known or screen-detected type 2 diabetes. Group 2, comprising the type 2 diabetic patients sampled at the Steno Diabetes Center ( $n=1,000 ; 609$ men, 391 women), was $59 \pm 11$ years old, was $52 \pm 11$ years at clinical diagnosis, had a BMI of $29.4 \pm 5.2 \mathrm{~kg} / \mathrm{m}^{2}$ and $\mathrm{HbA}_{1} \mathrm{c}$ of $8.1 \pm 1.6 \%$. Group $3(n=336 ; 159$ men, 177 women) was $62 \pm 5$ years old and had a BMI of $26.1 \pm 3.7 \mathrm{~kg} / \mathrm{m}^{2}$. All subjects in study groups 1 and 3 underwent a standard 75-g OGTT. The glucose-tolerant subjects in study group 1 were also examined in a study of quantitative traits. All participants were white Danes by self-report and were recruited from the same area of Denmark. Informed written consent was obtained from all subjects prior to participation. The study was approved by the Ethics Committee of Copenhagen and was conducted in accordance with the principles of the Declaration of Helsinki.

Type 2 diabetes, hypertension, obesity and the metabolic syndrome were defined according to the criteria set out by the WHO in 1999 [47]. Hypertension was defined as mean systolic blood pressure $\geq 140 \mathrm{~mm} \mathrm{Hg}$ and/or mean diastolic blood pressure $\geq 90 \mathrm{~mm} \mathrm{Hg}$ and/or current or previous treatment with antihypertensive drugs; obesity was defined as BMI $>30 \mathrm{~kg} / \mathrm{m}^{2}$ and/or WHR $>0.9$ (men) or $>0.85$ (women); and the metabolic syndrome was defined as type 2 diabetes or impaired glucose tolerance and/ or insulin resistance (by homeostasis model assessment of insulin resistance [HOMA-IR]) and any two of hypertension, dyslipidaemia, obesity or microalbuminuria.

Biochemical assays Blood samples were drawn after a 12-h overnight fast. Plasma glucose was analysed by a glucose oxidase method (Granutest; Merck, Darmstadt, Germany) 
Table 1 Genotype distribution and minor allele frequencies of the $825 C>T$ polymorphism of $G N B 3$ among type 2 diabetic patients and glucose-tolerant subjects

\begin{tabular}{llll}
\hline & $\begin{array}{l}\text { Glucose-tolerant } \\
\text { subjects }\end{array}$ & $\begin{array}{l}\text { Type 2 diabetic } \\
\text { subjects }\end{array}$ & $p$ value \\
\hline$n$ (men/women) & $\begin{array}{l}4,723(2,186 / \\
2,537)\end{array}$ & $\begin{array}{c}1,358(823 / \\
535)\end{array}$ & \\
Genotype & & & \\
CC & $2,323(49)$ & $618(46)$ & 0.007 \\
CT & $1,928(41)$ & $619(46)$ & \\
TT & $472(10)$ & $121(9)$ & 0.2 \\
MAF (\%) & $30.4(29.5-31.3)$ & $31.7(30.0-33.5)$ & 0.2 \\
\hline
\end{tabular}

Data are presented as number of subjects with each genotype (percentage (\%) of each group) and MAF in percent (\%) $(95 \% \mathrm{CI})$ The $p$ values were calculated using Fisher's exact test assuming a co-dominant model

and serum insulin (excluding des-31,32 and intact proinsulin) was measured using the AutoDELFIA insulin kit (Perkin-Elmer/Wallac, Turku, Finland). Serum C-peptide concentrations were measured by a time-resolved fluoroimmunoassay (AutoDELFIA C-peptide kit; Perkin-Elmer/ Wallac). Serum triglycerides and total, HDL and LDL serum cholesterol were analysed using enzymatic colorimetric methods (GPO-PAP and CHOD-PAP; Roche Molecular Biochemicals, Germany). $\mathrm{HbA}_{1} \mathrm{c}$ was measured by ion-exchange HPLC (normal reference range 4.1-6.4\%).

Genotyping Genotyping of the GNB3 $825 \mathrm{C}>\mathrm{T}$ polymorphism (dbSNP rs5443) was performed by chip-based matrix-assisted laser desorption/ionisation time-of-flight (MALDI-TOF) mass spectrometry (DNA MassARRAY; Sequenom, San Diego, CA, USA) of PCR-generated primer extension products, as described previously [49].

Statistical analysis Fisher's exact test, $\chi^{2}$ methods and logistic regression were applied to examine differences in allele and genotype frequencies between affected and unaffected subjects (all analysed as dichotomous traits,

Table 2 Genotype distribution and minor allele frequencies of the $825 C>T$ polymorphism of GNB3 among hypertensive and normotensive subjects

\begin{tabular}{llll}
\hline & $\begin{array}{l}\text { Normotensive } \\
\text { subjects }\end{array}$ & $\begin{array}{l}\text { Hypertensive } \\
\text { subjects }\end{array}$ & $p$ value \\
\hline N (men/women) & $4,193(1,818 /$ & $\begin{array}{l}3,139(1,837 / \\
1,302)\end{array}$ & \\
& $2,375)$ & & \\
Genotype & & $1,545(49)$ & \\
CC & $2,022(48)$ & $1,288(41)$ & 0.7 \\
CT & $1,744(42)$ & $306(10)$ & \\
TT & $427(10)$ & $30.3(29.1-31.4)$ & 0.4 \\
MAF (\%) & $31.0(30.0-32.0)$ &
\end{tabular}

Data are presented as number of subjects with each genotype (percentage (\%) of each group) and MAF in percent (\%) $(95 \% \mathrm{CI})$ The $p$ values were calculated using Fisher's exact test assuming a co-dominant model e.g. hypertension vs normotension). A general linear model was used to test for differences in variables (or transformed variables) between genotype groups in the populationbased samples of unrelated subjects. Only glucose-tolerant subjects were included in such analyses. Genotype and sex were considered as fixed factors, and age and BMI as covariates. Quantitative trait analyses and logistic regression were performed using the Statistical Package for Social Science, version 12.0 (SPSS, Chicago, IL, USA). Software for the case-control studies (Web-AssoTest) was downloaded from http://www.ekstroem.com (last accessed in October 2005). A $p$ value of less than 0.05 was considered to be significant. A meta-analysis of all studies was performed using RGui, version 1.9.0 (available at http:// mirrors.sunsite.dk/cran/). Homogeneity between studies was tested (Mantel-Haenszel) assuming a general model. Applying 39 biallelic SNP markers from 39 different genes

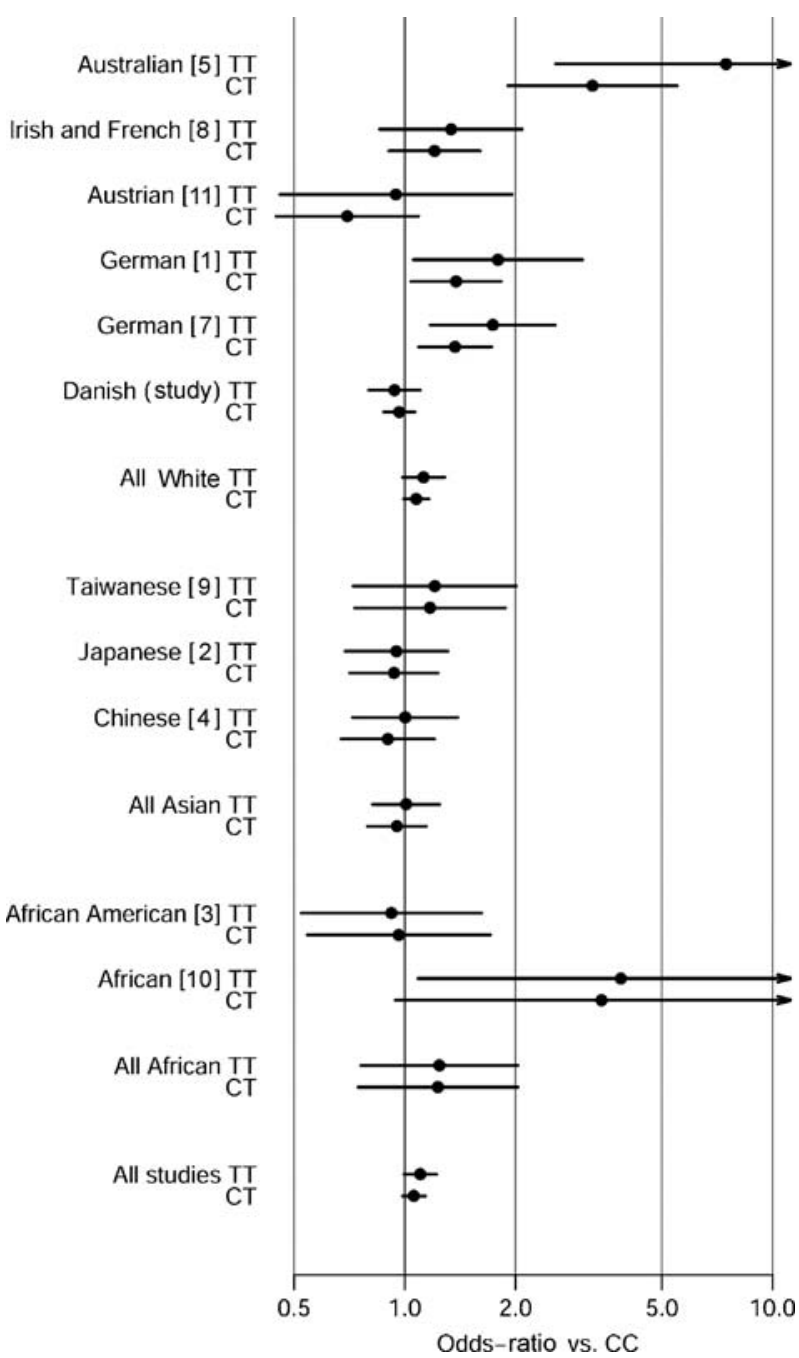

Fig. 1 Estimated risk $(95 \% \mathrm{CI})$ of developing arterial hypertension when carrying the GNB3 $825 \mathrm{~T}$ allele (CT and TT genotypes) in a meta-analysis of data from published case-control studies [1-5, 711] and from the present investigation stratified according to ethnicity and assuming a general model 
and using Structure, version 2.1 (http://pritch.bsd.uchicago. edu/structure.html) we made no observation of population stratification bias in the population-based sample of white Danes [50, 51].

\section{Results}

The GNB3 $825 \mathrm{C}>\mathrm{T}$ polymorphism was genotyped in a total of 7,518 participants. The genotyping success rate was

Table 3 Anthropometric and metabolic characteristics of 4,387 middle-aged glucose-tolerant white Danes stratified according to GNB3 $825 \mathrm{C}>\mathrm{T}$ genotype

\begin{tabular}{|c|c|c|c|c|c|}
\hline Parameter & \multicolumn{3}{|c|}{$825 \mathrm{C}>\mathrm{T}$ genotype } & $\begin{array}{l}p \text { value for co- } \\
\text { dominant model }\end{array}$ & $\begin{array}{l}p \text { value for } \\
\text { dominant mode }\end{array}$ \\
\hline$n$ (men/women) & $\begin{array}{l}2,156(1,001 / \\
1,155)\end{array}$ & $1,794(830 / 964)$ & $437(195 / 242)$ & & \\
\hline Age (years) & $45 \pm 8$ & $45 \pm 8$ & $46 \pm 8$ & & \\
\hline BMI $\left(\mathrm{kg} / \mathrm{m}^{2}\right)$ & $25.5 \pm 4.0$ & $25.4 \pm 4.0$ & $25.7 \pm 4.4$ & 0.5 & 1.0 \\
\hline Fasting (mmol/l) & $5.3 \pm 0.4$ & $5.3 \pm 0.4$ & $5.3 \pm 0.4$ & 0.9 & 0.6 \\
\hline $\begin{array}{l}\text { 30-min post-OGTT } \\
(\mathrm{mmol} / \mathrm{l})\end{array}$ & $8.2 \pm 1.5$ & $8.1 \pm 1.5$ & $8.1 \pm 1.5$ & 0.2 & 0.1 \\
\hline $\begin{array}{l}\text { 120-min post-OGTT } \\
(\mathrm{mmol} / \mathrm{l})\end{array}$ & $5.5 \pm 1.1$ & $5.5 \pm 1.1$ & $5.5 \pm 1.2$ & 0.6 & 0.3 \\
\hline Fasting (pmol/l) & $37 \pm 23$ & $37 \pm 22$ & $40 \pm 27$ & 0.4 & 0.6 \\
\hline $\begin{array}{l}\text { 30-min post-OGTT } \\
(\mathrm{pmol} / \mathrm{l})\end{array}$ & $289 \pm 187$ & $282 \pm 164$ & $297 \pm 181$ & 0.6 & 0.5 \\
\hline $\begin{array}{l}\text { 120-min post-OGTT } \\
(\mathrm{pmol} / \mathrm{l})\end{array}$ & $169 \pm 132$ & $165 \pm 123$ & $179 \pm 156$ & 0.4 & 0.3 \\
\hline $\begin{array}{l}\text { Post-OGTT AUC } \\
(\min \times[\mathrm{pmol} / 1])\end{array}$ & $21220 \pm 13996$ & $20571 \pm 12076$ & $22113 \pm 14857$ & 0.5 & 0.7 \\
\hline $\begin{array}{l}\text { HOMA-IR } \\
(\mathrm{mmol} / \mathrm{l} \times \mathrm{pmol} / \mathrm{l})\end{array}$ & $8.9 \pm 5.6$ & $8.8 \pm 5.5$ & $9.5 \pm 6.6$ & 0.4 & 0.6 \\
\hline \multicolumn{6}{|l|}{ Serum C-peptide } \\
\hline Fasting (pmol/1) & $542 \pm 213$ & $537 \pm 212$ & $543 \pm 223$ & 0.8 & 0.5 \\
\hline Systolic (mm Hg) & $128 \pm 16$ & $127 \pm 16$ & $126 \pm 15$ & $0.03 *$ & $0.03 *$ \\
\hline Diastolic (mm Hg) & $81 \pm 11$ & $80 \pm 10$ & $80 \pm 11$ & $0.04 *$ & $0.02 *$ \\
\hline \multicolumn{6}{|l|}{ Fasting serum lipids } \\
\hline Triglyceride (mmol/l) & $1.2 \pm 0.8$ & $1.2 \pm 1.1$ & $1.2 \pm 0.8$ & 0.8 & 0.7 \\
\hline Total cholesterol $(\mathrm{mmol} / \mathrm{l})$ & $5.4 \pm 1.0$ & $5.4 \pm 1.0$ & $5.4 \pm 1.0$ & 0.5 & 0.8 \\
\hline HDL cholesterol (mmol/l) & $1.5 \pm 0.4$ & $1.5 \pm 0.4$ & $1.4 \pm 0.4$ & 0.6 & 0.4 \\
\hline LDL cholesterol (mmol/l) & $3.5 \pm 1.0$ & $3.5 \pm 1.0$ & $3.4 \pm 0.8$ & 0.9 & 1.0 \\
\hline
\end{tabular}

Data are means \pm SD. Values of serum insulin, values derived from insulin variables, and values of serum triglyceride were logarithmically transformed before statistical analysis. The insulinogenic index was calculated as fasting serum insulin (pmol/l) subtracted from the 30-min post-OGTT serum insulin (pmol/l) and divided by the 30-min post-OGTT plasma glucose (mmol/1). HOMA-IR was calculated as fasting plasma glucose (mmol/l) multiplied by fasting serum insulin (pmol/1) and divided by 22.5

Calculated $p$ values were adjusted for age, sex and BMI, and were calculated assuming either a co-dominant or a dominant $(C / C C / T$ vs $T / T)$ $* p<0.05$ 
$96 \%$. The distribution of genotypes was nearly out of Hardy-Weinberg equilibrium in the total group $(p=0.05)$. A random selection of approximately $1 \%$ of the DNA samples was genotyped in duplicate without any discrepancies between genotype scores. We performed separate casecontrol studies of the association of the variant with type 2 diabetes, obesity, hypertension and the metabolic syndrome. Only for type 2 diabetes did we observe a relationship between $825 \mathrm{C}>\mathrm{T}$ genotype and affection status (Tables 1 and 2 and data not shown). Stratification according to sex and subsequent re-analysis did not change these results (data not shown). Likewise, employing a more strict definition of obesity (i.e. comparison of subjects with BMI $>30 \mathrm{~kg} / \mathrm{m}^{2}$ with subjects with a BMI $<25 \mathrm{~kg} / \mathrm{m}^{2}$ ) did not change the results (data not shown). Using Fisher's exact test we observed a significantly different uncorrected genotype distribution between glucose-tolerant subjects and type 2 diabetic patients $(p=0.007)$. There were no statistically significant differences in minor allele frequency (MAF) between the glucose-tolerant control subjects and the type 2 diabetic patients $(p=0.2)$. Using $\chi^{2}$ methods we obtained $p$ values of 0.007 and 0.02 for a co-dominant and a dominant model, respectively. Curiously, when comparing heterozygous $\mathrm{CT}$ carriers with wild-type $\mathrm{CC}$ carriers the odds ratio (OR) was 1.21 (95\% CI 1.06-1.37), while the odds ratio for homozygous TT carriers against CC carriers was 0.96 (95\% CI 0.77-1.20). Performing logistic regression with adjustment for age, sex and BMI we obtained $p$ values of 0.004 and 0.03 for the co-dominant and dominant model, respectively. We also included genotype data for the peroxisome proliferator-activated receptor- $\gamma 2$ Pro12Ala and Kir6.2 Glu23Lys polymorphisms as covariates in the logistic regression to investigate if the observed association was likely to be attributable to one or both of these known type 2 diabetes susceptibility variants; however, these adjustments did not substantially change the results for the GNB3 $825 \mathrm{C}>\mathrm{T}$ polymorphism ( $p=0.006$ and $p=0.05$, respectively).

Our case-control study of hypertension showed no relationship with the GNB3 polymorphism (Table 2). This could in part be due to a different phenotype assessment compared with previous studies (i.e. applying a different definition of hypertension). For some previous studies the inclusion criteria were not reported and for other studies a systolic/diastolic blood pressure of $160 / 95 \mathrm{mmHg}$ was used as a cut-off value. We employed these more strict criteria (genotype distribution: normotensive subjects $\mathrm{CC}=2,893, \mathrm{CT}=2,513$, $\mathrm{TT}=602$; hypertensive subjects $\mathrm{CC}=652, \mathrm{CT}=490, \mathrm{TT}=125, p=0.09 ; \mathrm{T}$ allele frequency: normotensive subjects $=30.9$ [95\% CI 30.1-31.8]; hypertensive subjects $=29.2[95 \%$ CI 27.4-31.0], $p=0.09$ ) and observed that, if anything, these results point towards the $\mathrm{C}$ allele conferring an increased risk of hypertension, whereas previous positive association studies suggest that the $\mathrm{T}$ allele is the hypertension risk allele. We performed a meta-analysis using data from previously published hypertension studies [1-5, 7-11] (Fig. 1). Due to large heterogeneity between studies (Mantel-Haenszel test, $p<0.0001$ ) we stratified the data according to ethnicity (white, Asian and African subjects). Following stratification, the criteria for between-study homogeneity remained unfulfilled for white subjects $(p<0.0001)$. However, when applying a dominant model the $\mathrm{T}$ allele was weakly associated with an increased risk of hypertension (OR $=1.08,95 \%$ CI $1.01-1.17$, $p=0.04$ ), and with an additive model the $\mathrm{T}$ allele was weakly associated, with an estimated odds ratio of 1.07 (95\% CI 1.01-1.13, $p=0.03$ ). For the Asian and African studies the criteria for homogeneity were met, but no relationship was seen between the variant and hypertension ( $p$ values ranging from 0.4 to 0.9 ). Using a general linear model we investigated a range of quantitative traits related to obesity, hypertension and type 2 diabetes (Table 3 ). Only mean values of systolic and diastolic blood pressure were nominally different between the genotype groups, where, contrary to the observations of most previously published studies, $\mathrm{T}$ allele carriers had slightly reduced blood pressure levels (Table 3).

\section{Discussion}

In the present study we have shown uncorrected statistically significant, but quantitatively minor and biologically negligible, differences in the distribution of the GNB3 $825 \mathrm{C}>\mathrm{T}$ genotypes between glucose-tolerant subjects and type 2 diabetic patients (Table 1). However, we failed to relate the variant with any quantitative metabolic variables. Furthermore, no significant associations of the variant were observed in case-control studies of obesity, hypertension or the metabolic syndrome. In a meta-analysis that included the present and previously published results on the variant in relation to hypertension, we observed an overall association of the T allele with an increased risk of hypertension (Fig. 1). However, as the statistical power of the present study to replicate the original finding of association between the variant and hypertension is estimated to be $99.96 \%$, we consider this variant to have, at best, only a minor influence on this cardiovascular disease.

The genotype distribution did not convincingly conform to Hardy-Weinberg equilibrium in our study sample. Moreover, large disparities in the frequency of the $825 \mathrm{~T}$ allele between populations of different ethnicities have been observed, ranging from as high as $65-91 \%$ among Africans, to $42-52 \%$ among Asians and $21-35 \%$ in Europeans [36]. Deviations from Hardy-Weinberg equilibrium were also observed in two studies of the GNB3 $825 \mathrm{C}>\mathrm{T}$ polymorphism in type 2 diabetes, one of which suggested that the $\mathrm{T}$ allele conferred a significantly increased risk of the disease $[31,52]$. We genotyped approximately $1 \%$ of our DNA samples in duplicate, and this yielded no discrepancies. Based on this, we consider our genotype data to be valid and not subject to genotype errors. Furthermore, there was no indication of population stratification bias in the study sample. Finally, when considering the large number of tests performed in this study at a $p$ value of 0.05 , we cannot exclude the possibility that the possible deviation from Hardy-Weinberg equilibrium is a false-positive observation. 
$\mathrm{G}$ proteins are key factors in the regulation of intracellular signalling pathways, one of which is involved in the regulation of transmembrane sodium exchange, which is often increased in insulin resistance. Given that the GNB3 $825 \mathrm{C}>\mathrm{T}$ polymorphism has been shown to be associated with enhanced $G$ protein activation in vitro [1], there may be a relationship between this polymorphism and type 2 diabetes (attributable to insulin resistance). Furthermore, insulin action and effect on glucose transport partly depends on a $\mathrm{G}$ protein-sensitive mechanism $[53,54]$. However, we did not observe any association between the GNB3 $825 \mathrm{C}>\mathrm{T}$ polymorphism and quantitative traits relating to insulin resistance and/or action (Table 3). Our finding of a relationship between the GNB3 $825 \mathrm{C}>\mathrm{T}$ polymorphism and type 2 diabetes is in contrast to a Japanese study that found no association between the $825 \mathrm{C}>\mathrm{T}$ polymorphism and type 2 diabetes in a population-based sample of 806 subjects [22]. We speculate that this may, in part, be due to the large differences in the $\mathrm{T}$ allele frequency between the present white Danish population (31\%) and the Japanese study sample $(49 \%)$. Our results are in agreement with those of a German study of 1,282 men [31], although the $\mathrm{T}$ allele was over-represented among the German type 2 diabetic men but was not among our diabetic population. In both studies, however, there was an over-representation of the CT genotype among the type 2 diabetic patients and a relative under-representation of the $\mathrm{CC}$ genotype. Moreover, we did not observe any relationships with diabetesrelated quantitative traits (Table 3). This observation is in contrast with the findings of a study in which the T allele was associated with higher fasting insulin concentrations among 261 non-diabetic Hispanic Americans [52]. In addition, a Polish study $(n=344)$ reported that the T allele was more frequent among type 2 diabetic patients than control subjects [13], and in a study of subjects from the United Arab Emirates $(n=510)$ the TT genotype was overrepresented among type 2 diabetic patients [32]. However, when considering the large number of statistical tests (at 95\% significance level) carried out in the present study and when applying a conservative Bonferroni correction for multiple testing, our result, although partly in agreement with previous observations, may be interpreted as a falsepositive observation.

Hypertension is the phenotype of the metabolic syndrome that has been most frequently studied in relation to the GNB3 825C>T polymorphism [1-15, 17]. In this study we did not show a relationship between the polymorphism and hypertension defined according to the WHO 1999 criteria. However, for a more severe form of hypertension we found suggestive evidence of a relationship with the polymorphism. In line with this, we observed nominally lower systolic and diastolic blood pressure levels among those with the TT genotype after adjustment for age, sex and BMI (Table 3). Still, these findings disagree with the general notion that the $\mathrm{T}$ allele is associated with an increased risk of hypertension, even though results similar to the present findings have been reported [11]. Nevertheless, given the size of the present study population, the lack of convincing confirmation of the initial findings of an association of the GNB3 $825 \mathrm{C}>\mathrm{T}$ polymorphism with hypertension in our case-control study, and the inconclusive result of the overall meta-analysis of all published studies, we conclude that the variant is not a major contributor to hypertension.

It has been suggested that the demonstration of an association of the $825 \mathrm{C}>\mathrm{T}$ polymorphism with various cardiovascular phenotypes is mediated through a primary effect of the 825T allele on obesity [25]. In the present study there was no evidence of a relationship of this allele with obesity or obesity-related traits. Case-control analyses of type 2 diabetes, hypertension and the metabolic syndrome, and quantitative trait analyses were made with adjustment for BMI and no deviations in BMI were observed between genotype groups (Table 3 ).

Even though the replacement of a $\mathrm{C}$ with a $\mathrm{T}$ at position 825 does not give rise to a change in the amino acid sequence, it can as such be used as an informative genetic marker with respect to the prediction of enhanced intracellular signal transduction, although it may be in linkage disequilibrium with an as yet unidentified variant in the non-coding region of GNB3 or in other genes (at the chromosome $12 \mathrm{p} 13$ locus) flanking GNB3. In summary, the GNB3 $825 \mathrm{C}>\mathrm{T}$ polymorphism does not seem to be a major contributor to the pathogenesis of the metabolic syndrome. We cannot exclude that the GNB3 $825 \mathrm{C}>\mathrm{T}$ polymorphism is associated with specific components of the metabolic syndrome; however, more large-scale genetic epidemiological studies are clearly needed in order to elucidate these potential relationships.

Acknowledgements The study was supported by the Faculty of Health Science at University of Copenhagen, the Danish Medical Research Council, the Danish Diabetes Association, the Danish Heart Foundation, the Velux Foundation, and European Economic Community (grant nos. BMH4-CT98-3084 and QLRT-CT-1999-00 546). The authors wish to thank A. Forman, I.-L. Wantzin and M. Stendal for technical assistance and G. Lademann for secretarial support.

\section{References}

1. Siffert W, Rosskopf D, Siffert G et al (1998) Association of a human G-protein $\beta 3$ subunit variant with hypertension. Nat Genet 18:45-48

2. Kato N, Sugiyama T, Morita H, Kurihara H, Yamori Y, Yazaki $Y$ (1998) G protein $\beta 3$ subunit variant and essential hypertension in Japanese. Hypertension 32:935-938

3. Larson N, Hutchinson R, Boerwinkle E (2000) Lack of association of 3 functional gene variants with hypertension in African Americans. Hypertension 35:1297-1300

4. Huang X, Ju Z, Song Y et al (2003) Lack of association between the $G$ protein $\beta_{3}$ subunit gene and essential hypertension in Chinese: a case-control and a family based study. J Mol Med 81:729-735

5. Benjafield AV, Jeyasingam CL, Nyholt DR, Griffiths LR, Morris BJ (1998) G-protein $\beta 3$ subunit gene (GNB3) variant in causation of essential hypertension. Hypertension 32:1094-1097

6. Hegele RA, Harris SB, Hanley AJG, Cao H, Zinman B (1998) $G$ protein $\beta 3$ subunit gene variant and blood pressure variation in Canadian Oji-Cree. Hypertension 32:688-692 
7. Beige J, Hohenbleicher H, Distler A, Sharma AM (1999) G-protein $\beta 3$ subunit C825T variant and ambulatory blood pressure in essential hypertension. Hypertension 33:1049-1051

8. Brand E, Herrmann S-M, Nicaud V et al (1999) The 825C/T polymorphism of the G-protein subunit $\beta 3$ is not related to hypertension. Hypertension 33:1175-1178

9. Tsai C-H, Yeh H-I, Chou Y et al (2000) G protein $\beta 3$ subunit variant and essential hypertension in Taiwan - a case-control study. Int J Cardiol 73:191-195

10. Dong Y, Zhu H, Sagnella GA, Carter ND, Cook DG, Cappuccio FP (1999) Association between the C825T polymorphism of the $\mathrm{G}$ protein $\beta 3$-subunit gene and hypertension in Blacks. Hypertension 34:1193-1196

11. Buchmayer H, Sunder-Plassmann G, Hirschl MM et al (2000) G-protein $\beta 3$ subunit gene $(G N B 3)$ polymorphism $825 \mathrm{C} \rightarrow \mathrm{T}$ in patients with hypertensive crisis. Crit Care Med 28:3203-3206

12. Snapir A, Heinonen P, Tuomainen T-P et al (2001) G-protein $\beta_{3}$ subunit C825T polymorphism: no association with risk for hypertension and obesity. J Hypertens 19:2149-2155

13. Dzida G, Golon-Siekierska P, Puzniak A et al (2002) G-protein $\beta 3$ subunit gene C825T polymorphism is associated with arterial hypertension in Polish patients with type 2 diabetes mellitus. Med Sci Monit 8:CR597-CR602

14. Sartori M, Semplicini A, Siffert W et al (2003) G-protein $\beta_{3^{-}}$ subunit gene $825 \mathrm{~T}$ allele and hypertension. A longitudinal study in young grade I hypertensives. Hypertension 42:909-914

15. Nürnberger J, Saez AO, Mitchell A et al (2004) The T-allele of the C825T polymorphism is associated with higher arterial stiffness in young healthy males. J Hum Hypertens 18:267-271

16. Jacobi J, Hilgers KF, Schlaich MP, Siffert W, Schmieder RE (1999) 825T allele of the G-protein $\beta_{3}$ subunit gene (GNB3) is associated with impaired left ventricular diastolic filling in essential hypertension. J Hypertens 17:1457-1462

17. Hengstenberg C, Schunkert H, Mayer B et al (2001) Association between a polymorphism in the $G$ protein $\beta 3$ subunit gene (GNB3) with arterial hypertension but not with myocardial infarction. Cardiovasc Res 49:820-827

18. Semplicini A, Siffert W, Sartori M et al (2001) G protein $\beta_{3}$ subunit gene $825 \mathrm{~T}$ allele is associated with increased left ventricular mass in young subjects with mild hypertension. Am J Hypertens 14:1191-1195

19. Sedlácek K, Fischer M, Erdmann J et al (2002) Relation of the $\mathrm{G}$ protein $\beta_{3}$-subunit polymorphism with left ventricle structure and function. Hypertension 40:162-167

20. Tabara Y, Kohara K, Miki T (2002) Polymorphisms of genes encoding components of the sympathetic nervous system but not the renin-angiotensin system as risk factors for orthostatic hypotension. J Hypertens 20:651-656

21. Wascher TC, Paulweber B, Malaimare L et al (2003) Associations of a human $G$ protein $\beta 3$ subunit dimorphism with insulin resistance and carotid atherosclerosis. Stroke 34:605-609

22. Yamamoto M, Abe M, Jin JJ et al (2004) Association of GNB3 gene with pulse pressure and clustering of risk factors for cardiovascular disease in Japanese. Biochem Biophys Res Commun 316:744-748

23. Benjafield AV, Lin RCY, Dalziel B, Gosby AK, Caterson ID, Morris BJ (2001) G-protein $\beta 3$ subunit gene splice variant in obesity and overweight. Int $\mathrm{J}$ Obes 25:777-780

24. Ohshiro Y, Ueda K, Wakasaki H, Takasu N, Nanjo K (2001) Analysis of $825 \mathrm{C} / \mathrm{T}$ polymorphism of $\mathrm{G}$ protein $\beta 3$ subunit in obese/diabetic Japanese. Biochem Biophys Res Commun 286:678680

25. Siffert W, Naber C, Walla M, Ritz E (1999) G protein $\beta 3$ subunit $825 \mathrm{~T}$ allele and its potential association with obesity in hypertensive individuals. J Hypertens 17:1095-1098

26. Zill P, Baghai TC, Zwanzger P et al (2000) Evidence for an association between a G-protein $\beta 3$-gene variant with depression and response to antidepressant treatment. NeuroReport 11:1893-1897

27. Lin C-N, Tsai S-J, Hong C-J (2001) Association analysis of a functional $\mathrm{G}$ protein $\beta 3$ subunit gene polymorphism (C825T) in mood disorders. Neuropsychobiology 44:118-121
28. Kunugi H, Kato T, Fukuda R, Tatsumi M, Sakai T, Nanko S (2002) Association study of C825T polymorphism of the G-protein $\beta 3$ subunit gene with schizophrenia and mood disorders. J Neural Transm 109:213-218

29. Fogarty DG, Zychma MJ, Scott LJ, Warram JH, Krolewski AS (1998) The C825T polymorphism in the human G-protein $\beta 3$ subunit gene is not associated with diabetic nephropathy in Type I diabetes mellitus. Diabetologia 41:1304-1308

30. Shcherbak N, Schwartz EI (2001) The C825T polymorphism in the G-protein $\beta 3$ subunit gene and diabetic complications in IDDM patients. J Hum Genet 46:188-191

31. Rosskopf D, Frey U, Eckhardt S et al (2000) Interaction of the G protein $\beta 3$ subunit T825 allele and the IRS-1 Arg 972 variant in type 2 diabetes. Eur J Med Res 5:484-490

32. Kiani JG, Saeed M, Parvez SH, Frossard PM (2005) Association of G-protein beta-3 subunit gene (GNB3) T825 allele with type II diabetes. Neuroendocrinol Lett 26:87-88

33. Krippl P, Langsenlehner U, Renner W et al (2004) The $825 \mathrm{C}>\mathrm{T}$ polymorphism of the G-protein beta-3 subunit gene (GNB3) and breast cancer. Cancer Lett 206:59-62

34. Lindemann M, Virchow S, Ramann F et al (2001) The $\mathrm{G}$ protein $\beta 3$ subunit $825 \mathrm{~T}$ allele is a genetic marker for enhanced T cell response. Fed Eur Biol Sci Lett 495:82-86

35. Siffert W, Rosskopf D, Moritz A et al (1995) Enhanced G protein activation in immortalized lymphoblasts from patients with essential hypertension. J Clin Invest 96:759-766

36. Siffert W, Forster P, Jöckel K-H et al (1999) Worldwide ethnic distribution of the $\mathrm{G}$ protein $\beta 3$ subunit $825 \mathrm{~T}$ allele and its association with obesity in Caucasian, Chinese, and Black African individuals. J Am Soc Nephrol 10:1921-1930

37. Levine MA, Modi WS, O'Brien SJ (1990) Chromosomal localization of the genes encoding two forms of the $\mathrm{G}$ protein $\beta$ polypeptide, $\beta 1$ and $\beta 3$, in man. Genomics 8:380-386

38. Ansari-Lari MA, Muzny DM, Lu J et al (1996) A gene-rich cluster between the CD4 and triosephosphate isomerase genes at human chromosome 12p13. Genome Res 6:314-326

39. Disse-Nicodème S, Achard J-M, Desitter I et al (2000) A new locus on chromosome 12p13.3 for pseudohypoaldosteronism type II, an autosomal dominant form of hypertension. Am J Hum Genet 67:302-310

40. Wiltshire S, Frayling TM, Groves CJ et al (2004) Evidence from a large UK family collection that genes influencing age of onset of type 2 diabetes map to chromosome $12 \mathrm{p}$ and to the MODY3/NIDDM2 locus on 12q24. Diabetes 53:855-860

41. Cantor RM, de Bruin T, Kono N et al (2004) Quantitative trait loci for apolipoprotein B, cholesterol, and triglycerides in familial combined hyperlipidemia pedigrees. Arterioscler Thromb Vasc Biol 24:1-7

42. Hegele RA, Anderson C, Young TK, Connelly PW (1999) G-protein $\beta 3$ subunit gene splice variant and body fat distribution in Nunavut Inuit. Genome Res 9:972-977

43. Hinney A, Geller F, Neupert T et al (2001) No evidence for involvement of alleles of the 825-C/T polymorphism of the G-protein subunit $\beta 3$ in body weight regulation. Exp Clin Endocrinol Diabetes 109:402-405

44. Suwazono Y, Okubo Y, Kobayashi E et al (2004) Lack of association between human G-protein $\beta 3$ subunit variant and overweight in Japanese workers. Obes Res 12:4-8

45. Fernández-Real JM, Peñarroja G, Richart C et al (2003) $\mathrm{G}$ protein $\beta 3$ gene variant, vascular function, and insulin sensitivity in type 2 diabetes. Hypertension 41:124-129

46. Alberti KGMM, Zimmet PZ (1998) Definition, diagnosis and classification of diabetes mellitus and its complications: Part 1. Diagnosis and classification of diabetes mellitus, provisional report of a WHO consultation. Diabetic Med 15:539-553

47. Jørgensen T, Borch-Johnsen K, Thomsen TF, Ibsen H, Glümer C, Pisinger C (2003) A randomized non-pharmacological intervention study for prevention of ischaemic heart disease: baseline results Inter99 (1). Eur J Cardiovasc Prev Rehabil $10: 377-386$ 
48. Drivsholm T, Ibsen H, Schroll M, Davidsen M, Borch-Johnsen K (2001) Increasing prevalence of diabetes mellitus and impaired glucose tolerance among 60-year-old Danes. Diabet Med 18:126-132

49. Buetow KH, Edmonson M, MacDonald R et al (2001) Highthroughput development and characterization of a genomewide collection of gene-based single nucleotide polymorphism markers by chip-based matrix-assisted laser desorption/ionization time-of-flight mass spectrometry. Proc Natl Acad Sci USA 98:581-584

50. Pritchard JK, Stephens M, Donnelly P (2000) Inference of population structure using multilocus genotype data. Genetics 155:945-959

51. Falush D, Stephens M, Pritchard JK (2003) Inference of population structure using multilocus genotype data: linked loci and correlated allele frequencies. Genetics 164:1567-1587
52. Parra EJ, Hoggart CJ, Bonilla C et al (2004) Relation of type 2 diabetes to individual admixture and candidate gene polymorphisms in the Hispanic American population of San Luis Valley, Colorado. J Med Genet 41:e116

53. Müller-Wieland D, White MF, Behnke B et al (1991) Pertussis toxin inhibits autophosphorylation and activation of the insulin receptor kinase. Biochem Biophys Res Commun 181:14791485

54. Krieger-Brauer HI, Medda PK, Kather H (1997) Insulininduced activation of NADPH-dependent $\mathrm{H}_{2} \mathrm{O}_{2}$ generation in human adipocyte plasma membranes is mediated by $\mathrm{G} \alpha_{\mathrm{i} 2}$. J Biol Chem 272:10135-10143 